\title{
The effect of protein inclusion level in diets formulated to contain an ideal amino acid composition for growing pigs
}

\author{
E. Pieterse ${ }^{\#}$, F.K. Siebrits, E.L. Gloy and A.K. Mphuloane \\ Agricultural Research Council, Animal Nutrition and Animal Products Institute, \\ Private Bag X 2, Irene, 0062
}

\begin{abstract}
The aim of the study was to determine the optimum protein inclusion level in diets containing an ideal amino acid balance for growing pigs. The performance of commercial crossbred grower-pigs was studied in two trials in which the experimental animals were housed either in commercial-type group housing (experiment1) or in individual pens (experiment 2). Treatments consisted of diets containing $14 \%, 16 \%, 18 \%$ or $20 \%$ crude protein. Lysine, tryptophan, threonine and total sulphur-containing amino acids were included in all diets at levels equivalent to that supplied by the $18 \%$ crude protein diet. In experiment one, 144 pigs ( 72 boars and 72 gilts) of initial mass $30 \mathrm{~kg}$ were fed until slaughter at $70 \mathrm{~kg}$. In experiment two, 80 pigs (40 boars and 40 gilts) of live masses ranging from 17.5 to $31.1 \mathrm{~kg}$ were fed until slaughter at masses between 64 and $105.5 \mathrm{~kg}$. There were no differences between treatments $(p>0,05)$ for daily gain, feed conversion ratio, daily intake or carcass classification, but feed conversion ratio differed between sexes in experiment two $(p<0.05)$. It was concluded that protein inclusion levels in pig growth diets could be decreased from $18 \%$ to $14 \%$ without any detrimental effect on performance, provided that the digestible essential amino acid composition is adjusted to meet requirements. This practice is however not economically viable for South African pig producers at the prevailing price of synthetic amino acids.
\end{abstract}

Keywords: pig, protein, amino acid, ideal amino acid profile, nitrogen pollution.

\#Author to whom correspondence should be addressed. E-mail: elsje@idpi1.agric.za

\section{Introduction}

The efficiency of protein utilisation by pigs is critical, not only from an economic perspective, but also because poorly metabolised nitrogenous feed components are ultimately recycled to the environment where they may contribute to nitrate pollution of soil and water. In order to avoid unnecessary wastage of dietary protein, it is important to feed pigs according to requirements. Requirements can be described in terms of the ideal amino acid composition of protein, which is an approximation of the ratio of amino acids in the body of the animal. A number of different amino acid combinations have been proposed for the ideal amino acid profile (ARC, 1981; Wang, 1988; Fuller et al., 1989; Wang \& Fuller, 1989; Kemm et al., 1990). Differences between these profiles are small, with the exception of that of ARC (1981) which contains comparatively low levels of tryptophan, phenylalanine and tyrosine.

Improvement of the efficiency of protein utilisation by pigs can be achieved in two ways: by supplying amino acids according to growth potential and physiological status (phase feeding; Lenis, 1989) or by improving dietary amino acid balance and concomitantly reducing dietary protein content (Henry, 1993). As phase feeding is expensive and difficult to implement, the latter strategy may represent an easier and more cost-effective alternative. The use of synthetic amino acids to balance dietary amino acids enables the level of intact dietary protein to be reduced, and significantly reduces nitrogen excretion (Sutton et al., 1999). Thus, the optimum combination of synthetic amino acids and locally available South African feedstuffs in low-protein diets for pigs may help to overcome protein shortages and reduce nitrate pollution. The aim of this experiment was to quantify the effects of reduced protein inclusion levels in diets formulated to contain an ideal amino acid balance, and to determine the economic implications of these diets.

\section{Materials and methods}

Two experiments were conducted. In experiment one, 144 (72 boars and 72 gilts) commercial-type crossbred grower-pigs were used. The pigs entered into the trial at an average live mass of $30 \mathrm{~kg}$ and were slaughtered at an average live mass of $70 \mathrm{~kg}$. Animals were kept in a temperature-controlled commercial grower facility consisting of 12 pens with 12 animals per pen (six boars and six gilts). Pens were equipped with self-feeders and automated water nipples. In experiment two, 80 (40 gilts and 40 boars) commercial-type crossbred grower-pigs were used. The pigs were housed individually and entered into the trial at live masses ranging from 17.5 to $31.1 \mathrm{~kg}$ and completed the trial at live masses ranging from 64 to $105.5 \mathrm{~kg}$. Animals were kept in a temperature-controlled grower facility in individual flat deck cages with perforated metal floors equipped with self-feeders and automatic water nipples.

Two summit diets containing either $14 \%$ or $20 \%$ crude protein were formulated according to the ideal amino acid 
pattern described by Kemm et al. (1990) for all amino acids except tryptophan, for which the value listed by Wang \& Fuller (1989) was used. These two diets were then blended in order to yield diets containing $16 \%$ and $18 \%$ crude protein, respectively. The levels of lysine, tryptophan, threonine, and total sulphur-containing amino acids in these two diets corresponded to that supplied by the $18 \% \mathrm{CP}$ diet. Feed was available ad libitum. The ingredient and nutrient composition of the diets are given in Tables 1 and 2.

Table 1 Ingredient composition of experimental diets containing different levels of crude protein (\%)

\begin{tabular}{|c|c|c|c|c|c|c|c|c|}
\hline \multirow[t]{2}{*}{ Ingredient $(\mathrm{kg})$} & \multicolumn{4}{|c|}{ Experiment 1} & \multicolumn{4}{|c|}{ Experiment 2} \\
\hline & $14 \%$ & $16 \%$ & $18 \%$ & $20 \%$ & $14 \%$ & $16 \%$ & $18 \%$ & $20 \%$ \\
\hline Maize & 83.9 & 79.00 & 74.38 & 69.48 & 78.58 & 72.07 & 65.76 & 59.44 \\
\hline Soya oil-cake meal & 7.49 & 9.50 & 11.40 & 13.41 & 0 & 0.67 & 1.32 & 1.97 \\
\hline Fishmeal & 4.20 & 5.66 & 7.04 & 8.50 & 4.40 & 2.90 & 1.45 & 0 \\
\hline Sunflower oil-cake meal & 0 & 2.01 & 3.90 & 5.91 & 0 & 0 & 0 & 0 \\
\hline Wheaten bran & 0 & 0 & 0 & 0 & 10.35 & 12.95 & 15.48 & 18.00 \\
\hline Gluten 60 & 0 & 0 & 0 & 0 & 2.03 & 6.77 & 11.36 & 15.95 \\
\hline Monocalcium phosphate & 2.16 & 1.78 & 1.43 & 1.05 & 1.42 & 1.44 & 1.46 & 1.48 \\
\hline Feed lime & 0.75 & 0.74 & 0.72 & 0.71 & 0.83 & 0.94 & 1.04 & 1.15 \\
\hline Salt & 0.75 & 0.74 & 0.72 & 0.75 & 0.75 & 0.75 & 0.75 & 0.75 \\
\hline L-Lysine HCL & 0.47 & 0.31 & 0.16 & 0 & 0.65 & 0.66 & 0.66 & 0.67 \\
\hline D/L-Methionine & 0.08 & 0.05 & 0.03 & 0 & 0.45 & 0.38 & 0.32 & 0.25 \\
\hline Threonine & 0 & 0 & 0 & 0 & 0.22 & 0.16 & 0.10 & 0.04 \\
\hline Tryptophan & 0 & 0 & 0 & 0 & 0.12 & 0.11 & 0.10 & 0.09 \\
\hline Vitamin and mineral premix $*$ & 0.40 & 0.40 & 0.40 & 0.40 & 0.40 & 0.40 & 0.40 & 0.40 \\
\hline
\end{tabular}

*Commercial non-medicated vitamin and mineral premix conforming to the standards of the ARC (1981).

Table 2 Estimated nutrient composition (as is basis) of experimental diets containing different percentages of crude protein

\begin{tabular}{|c|c|c|c|c|c|c|c|c|c|}
\hline \multirow[b]{2}{*}{ Nutrient } & \multirow[b]{2}{*}{ Unit } & \multicolumn{4}{|c|}{ Experiment 1} & \multicolumn{4}{|c|}{ Experiment 2} \\
\hline & & $14 \%$ & $16 \%$ & $18 \%$ & $20 \%$ & $14 \%$ & $16 \%$ & $18 \%$ & $20 \%$ \\
\hline Crude fibre & $(\%)$ & 3.3 & 3.4 & 3.6 & 3.7 & 3.2 & 3.4 & 3.6 & 3.8 \\
\hline DE pig & $(\mathrm{MJ} / \mathrm{kg})$ & 14.0 & 14.0 & 14.0 & 14.0 & 13.8 & 13.8 & 13.8 & 13.8 \\
\hline Crude protein & $(\%)$ & 14.0 & 16.0 & 18.0 & 20.0 & 13.5 & 15.6 & 17.6 & 19.6 \\
\hline Lysine & $(\%)$ & 1.00 & 1.02 & 1.03 & 1.05 & 1.00 & 1.00 & 1.01 & 1.01 \\
\hline TSSA & $(\%)$ & 0.61 & 0.66 & 0.70 & 0.75 & 0.84 & 0.87 & 0.91 & 0.95 \\
\hline Threonine & $(\%)$ & 0.51 & 0.58 & 0.65 & 0.72 & 0.63 & 0.65 & 0.67 & 0.69 \\
\hline Tryptophan & $(\%)$ & 0.16 & 0.19 & 0.22 & 0.25 & 0.20 & 0.20 & 0.21 & 0.21 \\
\hline Calcium & $(\%)$ & 0.9 & 0.9 & 0.9 & 0.9 & 1.0 & 0.9 & 0.9 & 0.9 \\
\hline Phosphorous & $(\%)$ & 2.8 & 2.6 & 2.5 & 2.3 & 2.8 & 2.6 & 2.5 & 2.3 \\
\hline Moisture & $(\%)$ & 94.2 & 93.8 & 94.3 & 94.6 & 93.6 & 93.9 & 94.3 & 94.4 \\
\hline
\end{tabular}

Feed residues from self-feeders were weighed every four days in experiment 1 , and weekly in experiment 2. Average daily gain and feed conversion ratio were estimated using a linear model for experiment 1 , and an autoregressive, allometric model (Siebrits, 1986) for experiment 2. Carcass mass and classification were noted at slaughter. Animals were weighed every four days in experiment 1 and weekly in experiment 2, corresponding with the intervals at which feed residues were weighed. Analysis of variance was performed on data from experiment 1 (Genstat 5, 1993). Because of the large variation in initial mass in experiment 2, an autoregressive allometric model (Siebrits, 1986) was used for data 
description, and the parameters estimated from the autoregressive allometric model were subject to analysis of variance (Genstat 5, 1993).

\section{Results and discussion}

Results for animals fed under group-housing conditions (experiment 1) are shown in Table 3, and those for animals fed in individual pens (experiment 2) are shown in Tables 4 and 5.

Table 3 Average daily intake, average daily gain (ADG), carcass classification and feed conversion ratio (FCR) ( \pm standard deviation) of animals kept under group housing conditions and fed different levels of crude protein (CP) from $30-70 \mathrm{~kg}$ live mass (experiment 1)

\begin{tabular}{lcccc}
\hline Treatment & $\begin{array}{c}\text { Average daily } \\
\text { intake }(\mathrm{kg})\end{array}$ & $\begin{array}{c}\text { ADG } \\
\text { (g/day) }\end{array}$ & $\begin{array}{c}\text { Carcass } \\
\text { classification* }\end{array}$ & $\begin{array}{c}\text { FCR } \\
\text { (kg feed/kg gain) }\end{array}$ \\
\hline $14 \% \mathrm{CP}$ & $1.8 \pm 0.29$ & $604 \pm 120$ & $\mathrm{P}$ & $2.69 \pm 0.11$ \\
$16 \% \mathrm{CP}$ & $1.9 \pm 0.18$ & $683 \pm 73$ & $\mathrm{P}$ & $2.46 \pm 0.07$ \\
$18 \% \mathrm{CP}$ & $1.8 \pm 0.14$ & $677 \pm 75$ & $\mathrm{P}$ & $2.40 \pm 0.08$ \\
$20 \% \mathrm{CP}$ & $1.8 \pm 0.18$ & $602 \pm 98$ & $\mathrm{P}$ & $2.52 \pm 0.17$ \\
\hline
\end{tabular}

No significant differences $(p>0.05)$ were observed for any of the parameters measured; $* \mathrm{P}=$ Calculated percentage carcass meat $\geq 70.1 \%$, based on electronic measurement of the hanging carcass between the second and third-last ribs $45 \mathrm{~mm}$ laterally from the carcass midline (Government gazette, 1992).

Table 4 Parameters ( \pm standard deviation) derived from the autoregressive allometric model (Siebrits, 1986) for animals fed in individual pens (experiment 2).

\begin{tabular}{clccccc}
\hline Treatment Sex & $\begin{array}{c}\alpha_{\mathrm{I}} \\
\ln (\mathrm{MJ})\end{array}$ & $\rho$ & $\begin{array}{c}\mu_{\mathrm{i}} \\
\ln (\mathrm{MJ})\end{array}$ & $\ln \mathrm{a}$ & $\mathrm{b}$ \\
\hline $14 \%$ & Boar & $8.645 \pm 0.252$ & $0.893 \pm 0.018$ & $6.371 \pm 0.197$ & $1.650 \pm 0.259^{\mathrm{a}}$ & $0.771 \pm 0.037^{\mathrm{a}}$ \\
& Gilt & $8.729 \pm 0.401$ & $0.904 \pm 0.019$ & $6.395 \pm 0.201$ & $1.532 \pm 0.154^{\mathrm{b}}$ & $0.754 \pm 0.022^{\mathrm{b}}$ \\
$16 \%$ & Boar & $8.737 \pm 0.274$ & $0.898 \pm 0.021$ & $6.382 \pm 0.199$ & $1.577 \pm 0.216^{\mathrm{a}}$ & $0.766 \pm 0.034^{\mathrm{a}}$ \\
& Gilt & $8.525 \pm 0.145$ & $0.888 \pm 0.013$ & $6.368 \pm 0.166$ & $1.591 \pm 0.177^{\mathrm{b}}$ & $0.765 \pm 0.026^{\mathrm{b}}$ \\
$18 \%$ & Boar & $9.158 \pm 0.845$ & $0.913 \pm 0.030$ & $6.360 \pm 0.151$ & $1.726 \pm 0.213^{\mathrm{a}}$ & $0.793 \pm 0.030^{\mathrm{a}}$ \\
& Gilt & $8.855 \pm 0.428$ & $0.909 \pm 0.019$ & $6.323 \pm 0.162$ & $1.413 \pm 0.161^{\mathrm{b}}$ & $0.741 \pm 0.022^{\mathrm{b}}$ \\
$20 \%$ & Boar & $8.651 \pm 0.316$ & $0.894 \pm 0.029$ & $6.370 \pm 0.176$ & $1.760 \pm 0.374^{\mathrm{a}}$ & $0.796 \pm 0.062^{\mathrm{a}}$ \\
& Gilt & $8.682 \pm 0.579$ & $0.899 \pm 0.027$ & $6.382 \pm 0.190$ & $1.423 \pm 0.233^{\mathrm{b}}$ & $0.743 \pm 0.034^{\mathrm{b}}$ \\
\hline
\end{tabular}

${ }^{a}$ Means within columns with different superscripts differ significantly $(p<0.05) ; \alpha_{\mathrm{I}}$ : Asymptote of $\ln ($ cumulative DE intake); $\rho$ : Slope of the autoregression; $\mu_{\mathrm{I}} \ln ($ cumulative DE intake) at the start of the experiment; $\mathrm{a}, \mathrm{b}$ : Intercept and slope of the regression equation; $\ln ($ live mass) $=\ln \mathrm{a}+\mathrm{b} \ln$ (cumulative DE intake)

Table 5 Average daily gain (ADG), feed conversion ratio (FCR), grams crude protein (CP) per kilogram gain and cost per kilogram gain ( \pm standard deviation) between $20 \mathrm{~kg}$ and $70 \mathrm{~kg}$ live mass for pigs fed diets containing various percentages of crude protein on an individual basis (experiment 2)

\begin{tabular}{llllll}
\hline Treatment & Sex & $\begin{array}{l}\text { ADG } \\
\text { (g/day) }\end{array}$ & $\begin{array}{l}\text { FCR } \\
\text { (kg feed/kg } \\
\text { gain) }\end{array}$ & $\begin{array}{l}\text { Protein } \\
\text { efficiency } \\
\text { (g CP/kg gain) }\end{array}$ & $\begin{array}{l}\text { Cost efficiency } \\
\text { (R/ kg gain) }\end{array}$ \\
\hline $14 \%$ & Boar & $832 \pm 113$ & $2.9 \pm 0.3$ & $406 \pm 36$ & 4.14 \\
& Gilt & $752 \pm 105$ & $3.0 \pm 0.2$ & $421 \pm 22$ & 4.28 \\
$16 \%$ & Boar & $891 \pm 115$ & $2.8 \pm 0.3$ & $387 \pm 35$ & 3.61 \\
& Gilt & $790 \pm 100$ & $2.9 \pm 0.2$ & $405 \pm 31$ & 3.74 \\
$18 \%$ & Boar & $1001 \pm 144$ & $2.5 \pm 0.3$ & $352 \pm 40$ & 2.83 \\
& Gilt & $797 \pm 122$ & $2.9 \pm 0.2$ & $418 \pm 25$ & 3.28 \\
& Boar & $938 \pm 236$ & $2.6 \pm 0.4$ & $364 \pm 62$ & 2.94 \\
& Gilt & $723 \pm 194$ & $2.9 \pm 0.3$ & $416 \pm 44$ & 3.28 \\
\hline
\end{tabular}


No significant differences $(p>0.05)$ were observed for any of the parameters measured

No differences $(p>0.05)$ were found between treatments for any of the performance parameters measured in either experiment. For the group-housed animals there was, however, a tendency $(p<0.10)$ for better ADG and FCR in the 16\% CP and 18\% CP groups (Table 3). FCR differed $(p<0.05)$ between sexes in the individually housed group. No differences in carcass classification were observed in either experiment; all the carcasses were classified as $P$, the leanest class of a sixclass scale. Despite a higher essential amino acid intake, the pigs fed the 20\% CP diet in both experiments performed no better than those fed the other diets. This was probably due to an oversupply of amino acids and the associated energy-cost of deamination. This is in agreement with the results of Henry et al. (1992) and D'Mello (1994) who reported that excess amino acid supply resulted in reduced protein utilization or reduced feed conversion efficiency and reduced mass gain. The results of this experiment, which are in agreement with those of Tuitoek et al. (1997), Lenis (1989) and Valaja et al. (1993), show that the efficiency of protein utilisation can be improved under South African conditions by formulating lowprotein diets containing with an optimal combination of synthetic amino acids and locally available South African feedstuffs.

Table 6 depicts economic scenarios for different synthetic amino acid prices when all other feed ingredient prices are kept constant. Due to the current (high) price of synthetic amino acids, the most economical diet was that containing $18 \% \mathrm{CP}$. It is also evident that the cost of the $16 \% \mathrm{CP}$ diet would be the lowest if the price of tryptophan were to decrease to that of methionine, (scenario 2). If the cost of all amino acids should, however, decrease to the current lysine price, the $14 \% \mathrm{CP}$ diet (scenario 3) would have the lowest cost per ton of feed.

Table 6 Different scenarios depicting the influence of synthetic amino acid price on feed cost for diets containing different levels of crude protein $(\mathrm{CP})$

\begin{tabular}{lccc}
\hline Diet CP content & $*$ Scenario 1 (R/ton) & $*$ Scenario 2 (R/ton) & *Scenario 3 (R/ton) \\
\hline $14 \% \mathrm{CP}$ & 1477 & 1138 & 1077 \\
$16 \% \mathrm{CP}$ & 1288 & 1113 & 1082 \\
$18 \% \mathrm{CP}$ & 1131 & 1114 & 1097 \\
$20 \% \mathrm{CP}$ & 1132 & 1132 & 1120 \\
\hline
\end{tabular}

*Scenario 1: Tryptophan R 41/kg; Threonine and methionine R 23/kg; Lysine R 11/kg

*Scenario 2: Tryptophan, threonine and methionine R 23/kg; Lysine R 11/kg

*Scenario 3: Tryptophan, threonine, methionine and lysine R $11 / \mathrm{kg}$

\section{Conclusion}

It was concluded that the protein inclusion levels in pig growth diets could be reduced from $18 \%$ to $14 \%$ without any significant detrimental effect on performance provided that the essential amino acid composition is adjusted. If the price of synthetic amino acids were to decrease, it would be possible to formulate diets containing less protein without adversely affecting production. The $20 \% \mathrm{CP}$ diet was not biologically or economically viable under any circumstances and is therefore not recommended.

\section{Acknowledgements}

The financial support provided by the Red Meat Research and Development Trust of South Africa for experiment 2 is gratefully acknowledged.

\section{References}

ARC, 1981. The nutrient requirements of pigs. Commonwealth Agricultural Bureaux, Slough.

D'Mello, J.P.F., 1994. Amino acid imbalances, antagonisms and toxicities. In: Animo acids in farm animal nutrition. Ed. D’Mello, J.P.F. CAB International, Wallingford. pp 63-97.

Fuller, M.F., McWilliam, R., Wang, T.C., \& Giles, L.R., 1989. The optimum dietary amino acid pattern for growing pigs.

2. Requirements for maintenance and for tissue protein accretion. Br. J. Nutr. 62, 255-267.

Genstat 5, 1993. Genstat 5 committee of the statistical department IACF - Rothamsted U.K., 1995. Genstat 5 Reference Manual. Clarendon press, Oxford.

Government Gazette, 1992. Regulation No. R. 1748. Agricultural Product Standards Act, 1990 (Act No. 119 of 1990).

Regulations regarding the classification and marking of meat. Government Gazette No. 14060, 26 June 1992.

Government Printer, Pretoria, South Africa. pp. 4-13. 
Henry, Y., Colleauz, Y. \& Seve, B., 1992. Effects of dietary level of lysine and of level and source of protein on feed intake, growth performance, and plasma amino acid pattern in the finishing pig. J. Anim. Sci. 70, 188-195.

Henry, Y., 1993. Self-selection of lysine by growing pigs: choice combinations between deficient or suboptimal and adequate or superoptimal dietary levels according to sex. Reprod. Nutr. Dev. 33, 489-502.

Kemm, E.H., Siebrits, F.K. \& Barnes, P.M., 1990. A note on the effect of dietary protein concentration, sex, type and live mass on whole-body amino acid composition of the growing pig. Anim. Prod. 51, 631-634.

Lenis, N.P., 1989. Lower nitrogen excretion in pig husbandry by feeding: current and future possibilities. Neth. J. Agric. Sci. 37, 61-70.

Siebrits, F.K., 1986. Application of the allometric autoregressive growth description in studies of growth and body composition. Pig news and information 7,413-418.

Sutton, A.L., Kephart, K.B., Verstegen, M.W.A., Canh, T.T. \& Hobbs, P.J., 1999. Potential for reduction of odorous compounds in swine manure through diet modification. J. Anim. Sci. 77, 430-439.

Tuitoek, K., Young, L.G., De Lange, D.F.M. \& Kerr, B.J., 1997. The effect of reducing excess dietary amino acids on growing-finishing pig performance: An evaluation of the ideal protein concept. J. Anim. Sci. 75, 1575-1583.

Valaja, J, Alaviuhkola, T. \& Suomi, K., 1993. Reducing crude protein content with supplementation of synthetic lysine and threonine in barley-rapeseed meal-pea diets for growing pigs. Agric. Sci. in Finl. 2, 117-123.

Wang, T.C. \& Fuller, M.F., 1989. The optimum dietary amino acid pattern for growing pigs. 1. Experiments by amino acid deletion. Br. J. Nutr. 62, 77-89.

Wang, T.C., 1988. The ideal dietary protein for growing pigs. PhD thesis: University of Aberdeen, UK. 